\section{Within- and between-person \\ variations as determinant \\ factors to calculate the number \\ of observations to estimate \\ usual dietary intake of \\ adolescents}

\section{Variação intra e interpessoal como fatores determinantes para o cálculo do número de observações para estimar a ingestão dietética habitual de adolescentes}

Mariana de M. F. Costa ${ }^{1}$

Lia Takeyama'

Sílvia M. Voci ${ }^{1}$

Betzabeth Slater ${ }^{1}$

Marina V. Silva²

${ }^{1}$ Department of Nutrition - School of Public Health - University of São Paulo, Brazil

2 Department of Agri-food industry, Food and Nutrition, "Luiz de Queiroz"

College of Agriculture, University of São Paulo, Brazil

\section{Resumo}

Este estudo transversal descreve a variabilidade do consumo alimentar de energia e macronutrientes a partir da estimativa dos coeficientes de variação intra e interpessoal e calcula o número de dias necessários para se avaliar a ingestão dietética de adolescentes de Piracicaba, Brasil. A amostra foi constituída por 92 adolescentes com idade entre 11 e 16 anos. Por meio de entrevistas, foram avaliadas variáveis demográficas, antropométricas e de ingestão dietética, levantada por meio de dois Recordatórios de 24h. Foram realizadas análises descritivas, sendo que as variâncias e os coeficientes de variação intra e interpessoal foram obtidos a partir dos resultados da ANOVA com um fator de classificação. O consumo médio de energia observado foi de 2.326,2 Kcal, e em relação aos macronutrientes foram observados valores de 89,0g de lipídios, 305,3g de carboidratos e 82,2g de proteínas. Os coeficientes de variação intrapessoal variaram de $36 \%$ a $45 \%$ enquanto os coeficientes de variação interpessoal variaram de $26 \%$ a $31 \%$. A razão entre as variâncias variou de 1,35 (carboidrato) a 2,62 (proteína). O menor número de observações necessárias para avaliar corretamente $(r=0,90)$ a dieta habitual foi de 6 dias para carboidratos. O maior número foi para proteínas (11 dias). Os coeficientes de variação foram semelhantes aos observados em estudos internacionais. Conclui-se que, para o presente estudo, duas observações foram suficientes para a obtenção de coeficientes de correlação razoáveis. No entanto, para se obter ótimos coeficientes de correlação, são necessárias no mínimo seis avaliações destes adolescentes.

Palavras-chave: Consumo alimentar. Razão de variância. Variação intra-pessoal. Variação interpessoal. Adolescentes.

Correspondence: Betzabeth Slater Department of Nutrition of the School of Public Health Av. Dr 


\section{Abstract}

This cross-sectional study describes the variation in the dietary intake of energy and macronutrients based on estimated coefficients of within- and between-person variation and intends to calculate the number of days required to evaluate the dietary intake of adolescents in Piracicaba, Brazil. The sample was made up by ninetytwo adolescents aged between eleven and sixteen years. Interviews were performed to assess demographic, anthropometric and dietary variables, which were evaluated by the answers obtained through two 24-hour recalls. Descriptive analyses were performed and variances and Coefficients of variation within- and between-person were obtained by results of one-way ANOVA. The mean energy intake observed was $2,326.2$ kilocalories; mean macronutrient intake came to 89.0 grams of fatty acids, 305.3 grams of carbohydrates and 82.2 grams of proteins. Coefficients of within-person variation ranged from $36 \%$ to $45 \%$, while between-person coefficients varied from $26 \%$ to $31 \%$. Variance ratios ranged from 1.35 (carbohydrate) to 2.62 (protein). The lowest number of observations required to correctly evaluate the usual diet calculated ( $r=0.90)$ was six days, for carbohydrates while the highest was eleven, for proteins. Coefficients of variation were similar to those observed in international studies. We conclude that, in this study, two observations were sufficient to obtain reasonable correlations. However, six evaluations are necessary for these adolescents in order to obtain excellent correlations.

Keywords: Dietary intake. Variance ratios. Within-person variation. Between-person variation. Adolescents.

\section{List of Abbreviations}

$\lambda$ : Variance Ratio

AFFQ: Adolescent Food Frequency Questionnaire

BMI: Body Mass Index

CV\%: Coefficient of variation

d: Number of estimated days

D: Estimated number of days of diet on record

FAPESP: Fundação de Amparo à Pesquisa do Estado de São Paulo

Kcal: Kilocalorie

kg: Kilogram

$\mathrm{m}$ : Meter

$\mathrm{m}^{2}$ : Square meter

R24h: 24-hour recall

$\mathrm{S}_{\mathrm{b}:}^{2}$ Between-person variance

$\mathrm{S}^{2}{ }_{\mathrm{w}}$ : Within-person variance

$\mathrm{SM}_{\mathrm{b}:}$ Between-person squared mean

$\mathrm{SM}_{\mathrm{w}}$ : Within-person squared mean

WHO: World Health Organization

\section{Introduction}

Evaluation of the dietary intake is the basis of nutritional epidemiology; therefore, it is essential to know the nature of the usual diet, since the effects of inadequate nutrient intakes will not appear in a matter of just a few days. Usual dietary intake can be defined as the mean nutrient or food intake over an extended period of time, during which the dietary pattern is followed, with multiple evaluations being required to obtain an estimate as close as possible to reality.

In that sense, an accurate estimate may be obtained by 24-hour recall collection (R24h), which take into account the descriptions and amounts of the related food. The short-term evaluation method is based on an interview held with a well-trained interviewer ${ }^{1}$. When correctly applied, the instrument satisfactorily reflects differences in intake by time, presenting highly variable estimates, especially due to day-to-day fluctuation and measurement errors ${ }^{2-4}$.

Diet variation comes from two basic sources: the ones observed within and between persons, which are vital in that 
they must be considered when evaluating the dietary intake of a single individual or group ${ }^{3}$.

Within-person variations may occur due to daily fluctuations, weekends, and seasonality. They are generally higher than between-person variation and can be defined as the variation between an individual's one-day intake and his/her own average. The widening of within-person variation in intake depends on food patterns, on the nutrient being evaluated, on the period of time evaluated and diet evaluation method ${ }^{3,5}$.

Between-person variation fluctuates according to nutrients and increases according to the heterogeneity of a population and to their usual food patterns. Thus, the variety of patterns will be extremely high if food intake is strongly influenced by individual patterns within the same group ${ }^{3,5}$.

Describing the variation sources of the diet is important in planning epidemiological studies seeing that it is essential to know the number of days of diet on record; this is required to evaluate food and nutrient intake with the utmost accuracy ${ }^{6}$.

The calculation of the number of days of diet on record is required to obtain the most correct intake evaluation, based on the ratio between variation values withinand between-person for each nutrient. The lower the ratio, the fewer repeated measurements needed ${ }^{6}$.

According to Nelson et al. ${ }^{6}$, the number of days of diet on record varies with the objective of the study. The present study, whose objective is to evaluate an individual's usual intake, will estimate the number of repeated measurements required for some dietary variables, as set forth by the authors.

On account of some aspects described hereinbefore and bearing in mind that the population under study has a nutritional changeability related to conditions that lead to a high variation in dietary intake, it is necessary to quantify the sources of variation and to determine the ratio between both; consequently, elements obtained are essential to estimate the number of repeated measurements required in order to attain the most precise evaluation of usual intake. This information is also relevant for planning healthcare actions, both in monitoring and in assessing such interventions, and also for the purpose of regulating commercial activities. Finally, data on adolescents' diet variability is scarce in Brazilian scientific literature.

This study was also conducted with the aim of estimating the number of dietary records to be assessed and to describe withinand between-person variation in energy and macronutrient intake among adolescents enrolled in public schools in the city of Piracicaba, in the State of São Paulo (Brazil), by using Coefficients of variation.

\section{Methods and Materials}

\section{Study subjects}

This cross-sectional study is based on data from a Calibration Study of the FoodFrequency Questionnaire for Adolescents - AFFQ, inserted in the main study, concerning diet, physical activity and body-mass index (BMI) of adolescents enrolled at public schools.

Subjects were eligible for this study if they were aged ten to sixteen years, of both genders, enrolled at public schools, in the State of São Paulo's city of Piracicaba. The initial sample included 94 adolescents.

This study was submitted to and approved by the Ethics Committee of the School of Public Health of the University of São Paulo.

\section{Epidemiological data collection}

Subjects were interviewed during August and September 2004. A non-dietary questionnaire and two non-consecutive 24-hour recalls were used. By using the non-dietary questionnaire, anthropometric measures were obtained to calculate the body mass index (BMI). Subsequently, the nutritional status of adolescents was classified using the World Health Organization (WHO) proposal ${ }^{7}$, according to gender and age, by 
analyzing the graphics drawn up by the National Center for Health Statistics (NCHS) ${ }^{8}$.

Information on the dietary intake of adolescents was gathered by performing the two 24-hour recalls with a 30 -day average interval between both. Interviews were performed by trained researchers to guarantee the quality of the information gathered; pictures of cutlery were used for better quantification of portions eaten, as suggested by Pereira et al. ${ }^{2}$ and Slater ${ }^{3}$.

The 24-h recalls were evaluated and standardized using tables drawn up by Fisberg \& Slater ${ }^{9}$, and Pinheiro et al. ${ }^{10}$.

Food intake was transformed into energy and macronutrients using the Nutrition Data System (NDS) software ${ }^{11}$. The final analysis included only adolescents presenting energy intakes between $500 \mathrm{kcal}$ and $6,000 \mathrm{kcal}^{12}$. Thus, ninety-two individuals comprised the final sample.

All parents provided informed consent and all procedures were approved by Research Ethics Committee of the University of São Paulo (nº 1173).

\section{Statistical analysis}

Descriptive analyses were performed and, aiming to estimate both within- and between-person variation coefficient, oneway ANOVA was used. All dietetic variables were normally distributed.

From information obtained by ANOVA (within-person squared mean - $\mathrm{SM}_{\mathrm{w}}$; and between-person squared mean - $\mathrm{SM}_{\mathrm{b}}$ ), it was possible to estimate between-person variance $\left(\mathrm{S}_{\mathrm{b}}^{2}\right)$ and within-person variance $\left(\mathrm{S}_{\mathrm{w}}^{2}{ }^{13}\right.$ :

$S_{W}^{2}=S M_{W}$

$S_{W}^{2}+k S_{b}^{2}=S M_{b}$

Where k represents the estimation number per individual, which, in this case $\mathrm{k}=2$.

By estimating $\mathrm{S}_{\mathrm{b}}{ }_{\mathrm{b}}$ and $\mathrm{S}^{2}{ }_{\mathrm{w}}$, it was possible to determine the Coefficient of variation (CV\%) and variance ratio $(\lambda)$ for better interpretation of the variance found in dietetic variables ${ }^{15}$ :
$C V_{w}=\left(S_{w} / \bar{x}\right) \times 100$

$C V_{b}=\left(S_{b} / \bar{x}\right) \times 100$

$\lambda=S_{w}^{2} / S_{b}^{2}$

Still, as described by Nelson et al. ${ }^{6}$, by calculating variance, it was possible to estimate the number of days of diet on record (D) required to obtain information on an individual's intake with a given level of accuracy, with a fixed $r$ value (which is the unobservable correlation coefficient between observed and true mean nutrient intakes of the population during the period of observation) that is to be chosen, depending on the level of accuracy of the results to be obtained. The equation used was the one given by Black et al. ${ }^{14}$ and Nelson et al. ${ }^{6}$, as follows:

$D=\frac{r^{2}}{1-r^{2}} \times \frac{S_{w}^{2}}{S_{b}^{2}}$

Therefore, $\mathrm{D}$ is influenced by the ratio between within- and between-person variations. If the variance observed throughout the days is smaller than the one between individuals, fewer repeated measurements should be evaluated. The value obtained for $\mathrm{D}$ also depends on the chosen $r$, thus, according to the desired $r$, the number of days to be recorded will be higher or lower ${ }^{6}$.

\section{Results}

The mean age of the 92 adolescents analyzed was thirteen years, and $70.7 \%$ of them were girls. As to anthropometric variables, the mean weight, $\mathrm{BMI}$ and height observed were $50.8 \mathrm{~kg}, 20.4 \mathrm{~kg} / \mathrm{m}^{2}$ and 1.57 $\mathrm{m}$, respectively.

Among the 92 adolescents, the average value of energy intake was $2326.18 \mathrm{kcal}$. Macronutrient average values were $89.03 \mathrm{~g}$, $305.31 \mathrm{~g}$ and $82.12 \mathrm{~g}$ to fat, carbohydrate and protein, respectively (Table 1 ).

Table 2 shows within- and between-person coefficients of variation and variance ratios $(\lambda)$. Within-person coefficients ran- 
ged from $35.69 \%$ (carbohydrate) to $44.90 \%$ (fat), while between-person coefficients ranged from $26.31 \%$ (protein) to $30.71 \%$ (carbohydrate). The lowest variance ratio ( $\lambda$ ) was obtained for carbohydrates (1.35), while the highest $\lambda$ was for proteins (2.62), proving that the within-person variability was always higher that the between-person one. These high ratios also indicate that it would be difficult to estimate adolescents' usual intake from few repeated observations mainly due to the complexity that surrounds the assessment of diet components among the adolescent population. This can be explained by their recognized high intake of energy due to the consumption of drinks sweetened with sugar and fried snacks.

Table 3 shows estimated values obtained for each nutrient for both $D$ and $r$. Values for $D$ were calculated based on a predetermined value of $r=0.9$ to provide information on energy and macronutrient intake. Values for $r$, useful to estimate the accuracy level of the results from this study, were obtained using the following equation:

$$
r=\left(\frac{d}{d+\frac{S_{w}^{2}}{S_{b}^{2}}}\right)^{1 / 2}
$$

Where $d$ represents the estimated number of days; in this study $d$ is represented by two observations ${ }^{6}$.

Coefficients $r$ ranged from 0.66 (protein), the least accurate evaluation, to 0.77 (carbohydrate), the most accurate one. Thus, the lowest number of days required to assess usual diet on this sample was obtained for carbohydrates (six days, approximately). Number of days for diet evaluation ranged from six to eleven. As a result, we may draw the conclusion that to achieve $r=0.9$, at least six (5.76) days of diet record necessary for carbohydrates, seven days are required to (6.82) to assess energy intake, ten days (10.19) to evaluate fat intake, and eleven (11.17) for protein.

Table 1 - Minimum, maximum and mean values for diet parameters obtained through two 24-hour recalls.

Tabela 1 - Valores mínimo e máximo e médias dos parâmetros dietéticos obtidos através de dois recordatórios de 24-horas.

\begin{tabular}{lcccc}
\hline \multirow{2}{*}{ Dietetic Variables } & \multicolumn{4}{c}{ Crude values } \\
& Mean & Standard Deviation & Minimum & Maximum \\
\hline Energy $(\mathrm{kcal})$ & $2,326.18$ & 883.50 & $1,045.20$ & $5,938.42$ \\
Fat $(\mathrm{g})$ & 89.03 & 38.30 & 35.42 & 253.08 \\
Carbohydrate $(\mathrm{g})$ & 305.31 & 121.36 & 117.68 & 744.61 \\
Protein $(\mathrm{g})$ & 82.15 & 32.84 & 28.89 & 202.29 \\
\hline
\end{tabular}

Table 2 - Values of within- $\left(\mathrm{S}_{\mathrm{w}}\right)$ and between-person variation $\left(\mathrm{S}_{\mathrm{b}}\right)$, coefficients of variation $(\mathrm{CV} \%)$ and variance ratios $(\lambda)$.

Tabela 2 - Valores de variabilidade intra- $\left(S_{w}\right)$ e interpessoal $\left(S_{b}\right)$, coeficientes de variância $(C V \%)$ e razões de variância $(\lambda)$.

\begin{tabular}{lccccc}
\hline Dietetic Variables & $\mathrm{S}_{\mathrm{w}}$ & $\mathrm{CV}_{\mathrm{w}}(\%)$ & $\mathrm{S}_{\mathrm{b}}$ & $\mathrm{CV}_{\mathrm{b}}(\%)$ & $\lambda$ \\
\hline Energy $(\mathrm{kcal})$ & 832.34 & 35.78 & 658.91 & 28.33 & 1.60 \\
Fat $(\mathrm{g})$ & 39.98 & 44.90 & 25.85 & 29.03 & 2.39 \\
Carbohydrate $(\mathrm{g})$ & 108.95 & 35.69 & 93.76 & 30.71 & 1.35 \\
Protein $(\mathrm{g})$ & 34.96 & 42.56 & 21.61 & 26.31 & 2.62 \\
\hline
\end{tabular}


Table 3 - Values of $r$ correlation coefficient and number of days required to evaluate usual diet (D).

Tabela 3 - Valores do coeficiente de correlação re número de dias necessários para avaliar a dieta habitual (D)

\begin{tabular}{lcc}
\hline Dietetic variables & $r^{+}$ & $\mathrm{D}^{+\dagger}$ \\
\hline Energy & 0.75 & 6.82 \\
Fat & 0.68 & 10.19 \\
Carbohydrate & 0.77 & 5.76 \\
Protein & 0.66 & 11.17 \\
\hline
\end{tabular}

${ }^{+}$Considering $\mathrm{d}=2$

${ }^{+\dagger}$ Considering $r=0.9$

\section{Discussion}

According to Willett ${ }^{15}$, diet can be considered a random event due to an individual's biological and behavioral features, having an impact on measures of association. Thus, evaluation of within- and between-person variation is a vital aspect, which must be taken into consideration to estimate the diet of both populations and individuals.

Comparing the data obtained by the present study with the averages obtained by Jahns et al..$^{16}$ in a study conducted with Russian and American adolescents aged nine to eighteen years, it is possible to notice that means of macronutrient and energy intake were higher for adolescents from Piracicaba.

Although Jahns et al. ${ }^{16}$ observed variance ratio values lower or equal to 1.0 for energy, proteins and carbohydrates in Russian adolescents, which means that the within-person variance attenuation effect on average intake is weaker, the values of variance ratios greater than 1.0, as the ones found in this study, can be explained by the large variety of food to be found in both medium-sized (like Piracicaba) and large cities $^{16}$. Hence, Piracicaba also has a rural area, which provides a greater diversity of edible items to the local community.

Persson et al. ${ }^{17}$, within an error of $20 \%$, in a study performed with Indonesian pregnant women, observed that six days of evaluation are needed to estimate the true usual intake for energy and carbohydrates. It has to be emphasized that this study is not for comparison to our study as the subjects are of different ages.

In fact, the essential number for diet estimation varies with the nutrient involved. It is widely accepted that a single day of evaluation cannot represent real intake, especially for some micronutrients. Accurate estimates of usual intake can be provided by multiple days of estimation of the same subject.

In validation studies, to obtain a reasonable estimate of an individual's true average intake, fourteen to twenty-eight repeated measurements are required per individual. On the other hand, it is well known that, in most studies conducted, it is not always feasible to obtain valid information from a high number of days. Therefore, Beaton ${ }^{18}$ states that three days of evaluation are sufficient, and actually, only three to five days are most commonly evaluated ${ }^{19}$.

According to a study by Nelson et al. ${ }^{6}$, with a fixed $r=0.9$, seven repeated measurements are not enough to accurately describe average intake for most micronutrients in boys aged five to seventeen years, while for girls a greater number of days of evaluation would be necessary for all nutrients, as well as for energy. The fact that the number of necessary repeated measurements presented by Nelson et al. ${ }^{6}$ is higher than the ones herein can be explained by the variance ratios obtained by Nelson et al. ${ }^{6}$, which were higher and reflected in the formula (6).

Scientific literature shows that variance from day-to-day, day of the week, and seasonality diet contribute to daily variation. Such factors are strengthened not only by sociocultural, economical and ecological aspects, but also by aspects related to both agro-industry and availability, usually influenced by a country's economical development.

Values for the ratio of the within- and between-person variances $(\lambda)$ higher than 1.0 are widely accepted and are the result of the within-person variance being higher than the between-person value. 
High within-person variation standards derive mainly from an individual's social behavior, as well as from other factors. According to Friis et al. ${ }^{20}$, Harbottle \& Duggan $^{21}$ and Tsubono et al. ${ }^{22}$ the extent of the variance is different for each nutrient. Authors state that regular nutrient intake (such as macronutrient intake) shows lower variance ratios in comparison with nutrients with high within-person variation. In the Piwoz et al. ${ }^{23}$ study, researchers demonstrate that within- and between-person variation depends also on the age and diversity of the food in the diet.

In Mantoanelli's ${ }^{24}$ study, they found that food intake variation by adolescents increased during the week. Another aspect to be considered is that $58 \%$ of the adolescents interviewed did not usually have breakfast during vacations, reflecting the broad variation in dietary intake during these days.

Yet, in the same study, two 24 -h recalls were insufficient to describe the adolescent's real dietary intake, within-person variation was high, resulting in real coefficient values that were far from what was expected (around 1.0). Moreover, seven repeated measurements were enough to describe this population's nutrient and energy intake.
Therefore, knowledge of the relationship between the two sources of variation is vital for the estimation of diet variables and, consequently, for the number of repeated measurements needed to obtain the most accurate results. By useing both variance values, it is possible to obtain information whereby diet information may be properly corrected, so as to adjust the distribution of the nutrient under study, which may enable an estimate of a nutrient's inadequacy.

In this study, due to the high withinperson variation and its attenuation effect, two evaluations were not enough to obtain good correlations. However, when the variation effect was removed, fair correlation coefficients were observed. In a hypothetical situation, in order to obtain a correlation coefficient close to 1.0 (like in the estimates presented earlier), using the data of this study, six evaluations are necessary.

\section{Acknowledgments}

This study was supported and funded by Fundação de Amparo à Pesquisa do Estado de São Paulo (FAPESP), a governmental foundation for supporting Brazilian research.

\section{References}

1. Jaime PC. Correções em medidas de consumo alimentar: aplicação na análise da correlação do consumo de cálcio, proteína e energia com a densidade mineral óssea em homens adultos e idosos [thesis for doctor's degree]. São Paulo: Faculdade de Saúde Pública da USP; 2001.

2. Pereira AML, Fisberg RM, Brasil ALD, Abreu VJS, Pacheco MEMS, Vasconcelos MIL. Métodos para avaliação do consumo alimentar em crianças e adolescentes. Rev Paul Pediatria 1997; 15 (4): 210-14.

3. Slater B. Desenvolvimento e validação de um questionário semi-quantitativo de freqüência alimentar para adolescentes [thesis for doctor's degree]. São Paulo: Faculdade de Saúde Pública da USP; 2001.

4. Thompson FE, Byers T. Dietary assessment resource manual. J Nutr 1994; 124(S): S2245-S2317.

5. Shils ME, Olson JA, Shike M, Ross AC. Tratado de nutrição moderna na saúde e na doença. Barueri: Manole; 2003.
6. Nelson M, Black AE, Morris JA, Cole TJ. Between- and within-subject variation in nutrient intake from infancy to old age: estimating the number of days required to rank dietary intakes with desired precision. Am J Clin Nutr 1989; 50: 155-67.

7. World Health Organization. Physical Status: The Use and Interpretation of Anthropometry. Geneva; 1995. (WHO Technical Report Series, 854).

8. Center for Disease Control and Prevention. National Center for Health Statistics. CDC Growth Charts, 2000. http://www.cdc.gov/growthcharts [Accessed $21 / 03 / 2004]$

9. Fisberg RM, Slater B. Manual de Receitas e Medidas Caseiras para Cálculo de Inquéritos Alimentares: manual elaborado para auxiliar o processamento de dados de inquéritos alimentares. São Paulo: Signus; 2002.

10. Pinheiro ABV, Lacerda EMA, Benzecry EH, Gomes MCS, Costa VM. Tabela para Avaliação de Consumo Alimentar em Medidas Caseiras. $4^{\text {th }}$ ed. Rio de Janeiro: Atheneu; 1998. 
11. NDS - Nutrition Data System for Research [computer program]. Version 11.5. Minneapolis (MN): University of Minnesota - NCC Food and Nutrient Database; 2005.

12. Andrade RG, Pereira RA, Sichieri, R. Consumo alimentar de adolescentes com e sem sobrepeso do Município do Rio de Janeiro. Cad Saúde Pública 2003; 19(5): 1485-95.

13. Slater B, Marchioni DL, Fisberg RM. Estimando a prevalência da ingestão inadequada de nutrientes. Rev Saúde Públ 2004; 38(4): 599-605.

14. Black AE, Cole TJ, Wiles SJ, White F (1983): Daily variation in food intake of infants from 2 to 18 months. Hum Nutr Appl Nutr 1983; 37A: 448-458.

15. Willett WC. Nutritional Epidemiology. $2^{\text {nd }}$ ed. New York: Oxford University Press; 1998.

16. Jahns L, Carriquiry A, Arab L, Mroz TA, Popkin BM. Within- and between-person variation in nutrient intakes of Russian and U.S. children differs by sex and age. J Nutr 2004; 134: 3114-20.

17. Persson V, Winkvist A, Hartini TNS, Greiner T, Hakimi $\mathrm{M}$, Stenlund $\mathrm{H}$. Variability in nutrient intakes among pregnant women in Indonesia: implications for the design of epidemiological studies using the 24-hour recall method. J Nutr 2001; 131: 325-30.

18. Beaton GH. Approaches to analysis of dietary data: relationship between planned analyses and choice of methodology. Am J Clin Nutr 1994 59(1): 253S-61S.
19. Cade J, Thompson R, Burley V, Warm D. Development, validation and utilization of food-frequency questionnaires - a review. Public Health Nutr 2002; 5(4): 567-87.

20. Friis S, Kruger Kjaer S, Stripp C, Overvad K. Reproducibility and relative validity of a selfadministered semiquantitative food questionnaire applied to younger women. J Clin Epidemiol 1997; 50: $303-11$.

21. Harbottle L, Duggan MB. Daily variation in food and nutrient intakes of Asian children in Sheffield. Eur J Clin Nutr 1994; 48: 66-70.

22. Tsubono Y, Fahey MT, Takahashi T, Iwase Y, Iitoi Y, Akabane M, Tsugane S. Interpopulation and intrapopulation variability of nutrient intake in five regions of Japan. Eur J Clin Nutr 1998; 52: 176-179.

23. Piwoz EG, de Kanashiro HC, de Romaña GL, Black RE, Brown KH. Within- and between-individual variation in energy intakes by low-income Peruvian infants. Eur J Clin Nutr 1994; 48: 333-340.

24. Mantoanelli G. Dieta habitual de adolescentes de uma escola estadual do Município de São Paulo [thesis for master's degree]. São Paulo: Faculdade de Ciências Farmacêuticas, Faculdade de Economia e Administração e Faculdade de Saúde Pública da USP; 2003.

Recebido em: 13/02/08

Versão final reapresentada em: 02/06/08

Aprovado em: 16/07/08 